\title{
PERAN CONTEXTUAL SUPPORT AND BARRIER TERHADAP CAREER INDECISION PADA MAHASISWA TINGKAT AKHIR
}

\author{
Dea Intan Pratiwi ${ }^{1}$, Sari Zakiah Akmal ${ }^{2}$ \\ ${ }^{1,2}$ Fakultas Psikologi, Universitas YARSI Jakarta \\ 1'deainpradip@gmail.com, ${ }^{2}$ sari.zakiah@gmail.com
}

\begin{abstract}
Abstrak. Individu yang sudah menempuh pendidikan tinggi diharapkan telah memperoleh kompetensi untuk menentukan pilihan karier. Akan tetapi, tidak semua mahasiswa tingkat akhir mudah dalam menentukan pilihan karier, ada pula diantaranya yang mengalami kebingungan atau ketidakmampuan untuk menentukan pilihan karier atau yang disebut sebagai career indecision. Faktor penting yang secara langsung dapat mempengaruhi pilihan karier individu adalah faktor eksternal atau yang disebut sebagai contextual support and barrier. Penelitian ini dilakukan untuk mengetahui bagaimana peranan contextual support and barrier terhadap career indecision pada mahasiswa tingkat akhir di Indonesia. Penelitian ini merupakan penelitian asosiatif yang melibatkan 320 mahasiswa yang berkuliah di Indonesia, yang diperoleh dengan teknik sampel incidental sampling. Hasil penelitian menunjukkan bahwa contextual support and barrier berperan sebesar $10.9 \%$ terhadap career indecision yang dirasakan mahasiswa tingkat akhir. Contextual barrier berperan secara signifikan terhadap career indecision pada mahasiswa tingkat akhir.
\end{abstract}

Kata kunci: Career Indecision, Contextual Support and Barrier, Mahasiswa Tingkat Akhir

Abstract. Individuals who have higher education are expected to have acquired the competence to determine career choice. However, not every final-year college student are easy in determining career options, some of them are experiencing confusion or inability to choose their career or what is called career indecision. Important factors that can directly affect the individual's career choice is an external factor which are contextual support and barrier. This research was conducted to find out how the role of contextual support and barrier to career indecision among the final grade students in Indonesia. The method used in this study was associative research. Subjects in this study were 320 students who studying in Indonesia. The results showed that contextual support and barrier have a significant role toward the student's perceived career indecision by $10.9 \%$. The contextual barrier has a significant role for the career indecision in the final grade students.

Keywords : Career Indecision, Contextual Support And Barrier, Final-year Student 
Setiap tahunnya, jumlah lulusan sarjana di Indonesia mengalami peningkatan. Organization for Economic Co-operation and Development (OECD) memperkirakan bahwa pada tahun 2020 Indonesia akan menjadi negara dengan jumlah lulusan sarjana terbanyak ke lima (Mohamad, 2012). Jumlah lulusan sarjana yang semakin meningkat tidak diimbangi dengan kesiapan mahasiswa untuk masuk ke dalam dunia kerja (Helmi, 2004). Lulusan sarjana diharapkan memiliki kesiapan untuk masuk ke dalam dunia kerja, sehingga dapat meminimalisir angka pengangguran lulusan perguruan tinggi (Helmi, 2004; Daniel, 2013). Beberapa tahun terakhir tetap terjadi peningkatan angka pengangguran lulusan sarjana di Indonesia (Kementrian Ketenagakerjaan dan Transmigrasi, 2011). Berdasarkan data yang terdapat di Badan Pusat Statistik (2016), terjadi peningkatan jumlah pengangguran lulusan sarjana. Pada tahun 2015 berjumlah 653,586 orang sedangkan pada tahun 2016 menjadi sejumlah 695,304 orang. Hal ini merupakan salah satu akibat dari mahasiswa yang belum mengetahui bidang pekerjaan yang ingin dicapai (Helmi, 2004).

Individu yang sudah menempuh pendidikan tinggi diharapkan telah memperoleh kompetensi dan keahlian untuk menentukan pilihan kariernya (Nile \& Bowlsbey, 2009; Rachmawati, 2012; Primasuari, 2015). Sayangnya, tidak semua individu memiliki kompetensi dan mampu menentukan pilihan kariernya (Tien, 2001; Creed, Patton, \& Prideaux, 2006). Kondisi dimana individu tidak mampu menentukan pilihan karier disebut sebagai career indecision. Menurut Callanan dan Greenhaus (2006) career indecision adalah ketidakmampuan seseorang dalam mengambil keputusan untuk memilih suatu karier. Career indecision merupakan ketidakmampuan individu dalam menentukan pilihan pendidikan dan pekerjaan sesuai keinginannya (Guay, Ratelle, Senécal, Larose, \& Deschênes 2006; Hartung, Porfeli, \& Vondracek, 2008).

Creed dan Patton (dalam Creed, Patton \& Prideaux, 2006) mengatakan bahwa proses menentukan karir, terjadi pada masa transisi. Salah satunya dialami oleh mahasiswa tingkat akhir hingga individu tersebut mendapatkan pekerjaan (Koen, Klehe, \& Vianen, 2012). Periode usia mahasiswa tingkat akhir adalah antara rentang usia 21-24 tahun (Roellyana \& Listiyandini, 2016). Super menjelaskan bahwa berdasarkan tugas perkembangan, individu yang berusia $21-24$ tahun seharusnya sudah mampu untuk mengkristalisasikan atau membuat pilihan karier yang spesifik (Brown \& Lent, 2005). Akan tetapi masih terdapat mahasiswa tingkat akhir yang belum mampu menentukan pilihan kariernya. Berdasarkan penelitian yang dilakukan oleh Rachmawati (2012) terhadap mahasiswa tingkat akhir pada salah satu universitas di Indonesia, menunjukkan bahwa partisipan pada penelitiannya belum memiliki perencanaan, pembuatan keputusan karir dan keterampilan yang cukup baik dalam memilih karier. Sejalan dengan penelitian Rachmawati, penelitian Hami, Hinduan, dan Sulastiana menunjukkan bahwa partisipan pada penelitian tersebut belum dapat menentukan pilihan karir dan partisipan masih merasa kurang dalam perencanaan karier (Kartika \& Arlinkasari, 2015).

Ketika mahasiswa tingkat akhir mengalami career indecision, hal tersebut dapat berdampak kepada performa mereka ketika sudah bekerja. Latief (2010) dan Harahap (2014), menyatakan bahwa lulusan perguruan tinggi yang memilih pekerjaan secara asal, dapat menghasilkan karyawan yang kurang kompeten dan tidak mampu untuk menghadapi tantangan di dunia kerja. Hal tersebut juga dapat menimbulkan perilaku berpindah-pindah pekerjaan ketika sudah bekerja. Berdasarkan survey PT. Unilever 
Indonesia ditemukan bahwa sebanyak $60 \%$ persen pekerja di Indonesia gemar untuk berpindah-pindah pekerjaan, karena partisipan merasa bekerja tidak sesuai dengan keinginan (Ngantung, 2013). Tidak hanya itu, karyawan yang berpindah-pindah pekerjaan dapat pula memberi dampak yang negatif bagi perusahaan, yaitu membuat perusahaan mengalami kerugian dari segi materi, karena perusahaan harus mengeluarkan biaya kembali untuk melakukan perekrutan ulang calon pekerja. Dampak-dampak tersebut membuat perlu dilakukannya penelitian terhadap mahasiswa tingkat akhir yang mengalami career indecision. Dalam hal ini, career indecision merupakan bagian dari proses pemilihan karier, dimana proses pemilihan karier terdapat didalam tugas perkembangan karier sesorang (Berdick, Bernes, Magnusson \& Witko, 2004; Creed, Patton \& Prideaux, 2006).

Menurut Bandura (2002) dan Lent, Hackett \& Brown (2000), salah satu teori yang sesuai untuk menjelaskan perkembangan karier sesorang adalah Social Cognitive Career Theory (SCCT), teori ini merupakan upaya untuk mengembangkan teori kognitif sosial dalam prilaku karier (Lent \& Brown, 2003). Lent, Hackett \& Brown (2000) mengungkapkan bahwa dalam teori SCCT terdapat dua faktor yang mempengaruhi pilihan karier seseorang yaitu, faktor kognitif individu (self efficacy, outcome expectation dan goal orientation) dan faktor contextual (support and barrier). Faktor eksternal merupakan faktor penting yang secara langsung dapat mempengaruhi individu dalam menentukan pilihan kariernya, dan lebih banyak berpengaruh terhadap proses penentuan pilihan seseorang (Lent, Hackett \& Brown, 2000; Lent \& Brown, 2003). Faktor contextual dapat menjadi support (dukungan) dan sebagai barrier (hambatan) dalam proses pemilihan karier seseorang. Menurut Lent, Hackett \& Brown (2000), beberapa aspek yang termasuk kedalam contextual support and barrier, seperti; gender, institusi pendidikan, ras dan culture, sosio ekonomi, keluarga, dan teman.

Menurut ILO, Keller dan Whiston dalam Ukil (2016), faktor seperti orang tua atau keluarga, kondisi sosial politik, prospek kerja yang cukup dan konseling karier berperan penting dalam pengambilan keputusan karier. Faktor eksternal dapat menimbulkan masalah dalam proses pemilihan karier (Ukil, 2016). Sejalan dengan Ukil (2016), hasil penelitian yang dilakukan oleh Kartika dan Arlinkasari (2015) menunjukkan bahwa individu yang mendapatkan dukungan dari lingkungan eksternal menunjukkan kemampuan dalam memilih karier yang baik, sedangkan pada individu yang mendapatkan hambatan dari lingkungan eksternal menunjukkan kemampuan dalam memilih karier yang kurang baik.

Berdasarkan hasil penelitian yang dilakukan oleh Huang dan Hseih (2011), status ekonomi sosial individu, dapat memprediksi keyakinan individu dalam menentukan pilihan karier. Penelitian yang dilakukan oleh Anggraini (2012), menunjukkan bahwa mahasiswa yang memiliki latar belakang ekonomi rendah memiliki kemampuan dalam menentukan pilihan karier yang rendah pula. Kemudian, menurut Huang dan Hseih (2000); Lee (2001), faktor keluarga berperan dalam menentukan pilihan karier atau pekerjaan. Pilihan karier mahasiswa disesuaikan dengan penerimaan yang diberikan oleh keluarga terhadap pekerjaan atau karier yang sudah mereka pilih (Huang dan Hseih, 2011; Lee, 2001). Menurut Lent, Hacket \& Brown (2000) pada keluarga dengan budaya kolektivis, keluarga memiliki peran yang penting dalam menentukan pilihan karier individu. 
Penelitian lain yang dilakukan oleh Leong (dalam Huang \& Hseih, 2011) mengungkapkan bahwa pemuda Asia-Amerika memilih pekerjaan disesuaikan dengan persetujuan yang diberikan oleh orangtua. Sedangkan berdasarkan hasil penelitian yang dilakukan oleh Mau (2000), bagi seseorang dengan latar belakang keluarga individualis, dalam menentukan pilihan cenderung membuat keputusan karier untuk dirinya sendiri. Maka, dapat dikatakan bahwa contextual support and barrier berdampak pada individu dengan latar belakang keluarga budaya kolektivis, dan bagi individu dengan latar belakang budaya individualis (Lent, Hackett \& Brown, 2000).

Hofstede dalam Septarini dan Yuwono (2003) menempatkan Indonesia sebagai bangsa dengan nilai budaya kolektivis yang tinggi, dibandingkan dengan India, Jepang, Malaysia, Philipina dan negara-negara Arab. Pada budaya ini, ketika seseorang menentukan pilihan karier, cenderung bergantung terhadap lingkungan sosialnya, dan memiliki rasa terikat yang kuat dalam suatu kelompok (Hofstede dalam Septarini \& Yuwono, 2003). Nguyen (2011) dalam penelitiannya menyatakan bahwa, perlu dilakukan penelitian lebih banyak terkait faktor eksternal yang dapat mempengaruhi pemilihan karier seseorang khususnya pada budaya kolektivis, karena dalam pemilihan karier, faktor eksternal sering tidak menjadi perhatian. Oleh karena itu, penelitian ini menjadi penting untuk dilakukan di Indonesia dengan budaya kolektivis.

Berdasarkan uraian tersebut permasalahan yang akan dijawab dalam penelitian ini adalah "apakah terdapat peranan contextual support and barrier terhadap career indecision pada mahasiswa tingkat akhir?". Tujuan dari penelitian ini untuk melihat peranan contextual support and barrier terhadap career indecision pada mahasiswa tingkat akhir. Sejalan dengan itu, hipotesa penelitian ialah terdapat peranan contextual support and barrier terhadap career indecision mahasiswa tingkat akhir.

\section{METODE}

Subjek dalam penelitian ini berjumlah 320 mahasiswa tingkat akhir di Indonesia dengan rentang usia 21-24 tahun. Subjek diperoleh dengan menggunakan teknik incidental sampling. Data penelitian diperoleh dengan menyebarkan kuesioner dan melalui online.

Variabel terikat dalam penelitian ini adalah career indecision. Definisi operasional career indecision adalah skor yang didapat dari pengukuran terhadap 4 dimensi, yaitu: lack of structure, external barrier, approach-approach conflict, dan personal conflict yang disusun oleh Osipow, dkk. (1976). Semakin tinggi skor total dari CDS akan menunjukkan tingginya tingkat career indecision yang dialami individu, begitu pula sebaliknya.

Variabel bebas dalam penelitian ini adalah contextual support and barrier. Definisi operasioanl dari contextual support and barrier merupakan skor yang didapat dari pengukuran 2 dimensi, yaitu support dan barrier yang disusun oleh Lent, Brown dan Hackett (2003). Untuk melihat contextual support and barrier yang diterima seseorang, dapat diketahui melalui hasil total skor pada masing-masing dimensi. Semakin tinggi skor pada setiap dimensi maka semakin menunjukkan contextual support and barrier yang dirasakan seseorang. 
Instrumen penelitian yang digunakan dalam penelitian ini adalah kuesioner yang terdiri dari 3 bagian, yaitu: 1. Data demografi, 2. Skala Career Decision Scale (CDS) yang terdiri atas 16 aitem dengan koefisien reliabilitas Cronbach Alpha 0,878, dan 3. Skala Contextual Support and Barreir (CSB) yang terdiri atas dua dimensi. Dimensi Contextual Suppot memiliki 15 aitem dengan koefisien reliabilitas Cronbach Alpha 0.876 sedangkan dimensi Contextual Barrier terdiri atas 23 aitem dengan koefisien reliabilitas Cronbach Alpha 0,939.

Analisis regresi digunakan untuk memprediksikan seberapa jauh perubahan nilai variabel kriteria bila nilai variabel prediktor dimanipulasi atau dirubah-rubah atau dinaikturunkan. Dalam penelitian ini, analisis regresi yang digunakan adalah regresi ganda, dimana peneliti bermaksud meramalkan bagaimana keadaan (naik turunnya) variabel kriteria, bila dua atau lebih variabel prediktor dimanipulasi (dinaik turunkan nilainya) (Sugiyono, 2013). Sebelum melakukan analisa regresi, dilakukan uji normalitas dan linearitas data.

\section{HASIL}

Berdasarkan hasil yang diperoleh pada tabel 1 mayoritas partisipan $(75,6 \%)$ penelitian berjenis kelamin perempuan. Sebanyak 50,9\% partisipan berasal dari universitas swasta, dengan 79,7\% diantaranya memiliki IPK 3,1-4,0. Kemudian, 60,3\% partisipan memilih perkuliahan yang saat ini dijalani sebagai pilihan yang pertama dan 83,4\% memilih perkuliahan berdasarkan keinginan dari diri sendiri. Sebanyak 95,0\% partisipan telah memiliki rencana kerja setelah lulus kuliah. Berikut ini adalah tabel deskripsi data demografis subjek penelitian pada Tabel 1 .

Tabel 1. Deskripsi Subjek Penelitian

\begin{tabular}{ccc}
\hline \multicolumn{1}{c}{ Variabel } & Jumlah & Presentase (\%) \\
\hline Jenis Kelamin & 78 & 24,4 \\
Laki-laki & 242 & 75,6 \\
Perempuan & & \\
Universitas & 157 & 49,1 \\
Negeri & 163 & 50,9 \\
$\quad$ Swasta & & \\
IPK & 65 & 20,3 \\
2,1-3,0 & 255 & 79,7 \\
3,1-4,0 & & \\
Pilihan kuliah yang ke & 193 & 60,3 \\
1 & 89 & 27,8 \\
2 & 28 & 8,8 \\
3 & 10 & 3,1 \\
4 & & \\
Jurusan ini keinginan dari & 267 & 83,4 \\
Diri sendiri & 34 & 10,6 \\
Ayah/ Ibu & 5 & 1,6 \\
Mengikuti Teman & 14 & 4,4 \\
Lain-lain &
\end{tabular}


Berikut ini adalah tabel hasil uji hipotesa penelitian dengan menggunakan teknik analisa regresi linear.

Tebel 2. Hasil Uji Regresi

\begin{tabular}{cccc}
\hline Model & & F & Sig. \\
\hline 1 & Regression Residual & 19,455 & 0,000 \\
\hline
\end{tabular}

Berdasarkan tabel 2, dapat diketahui bahwa nilai signifikan yang diperoleh yaitu $\mathrm{p}=0,000$ $(\mathrm{p}=<0,05)$. Hal tersebut menunjukkan bahwa contextual support and barrier secara bersama-sama berperan terhadap career indecision pada mahasiswa tingkat akhir di Indonesia.

Tabel 3. Uji Regresi Ganda

\begin{tabular}{clllll}
\hline Model & R & R-Square & $\begin{array}{l}\text { Adjusted } \\
\text { Square }\end{array}$ & R- $\begin{array}{l}\text { Std. Error of } \\
\text { Estimate }\end{array}$ \\
\hline 1 & 0,432 & 0,109 & 0,104 & 6,973 \\
\hline
\end{tabular}

Berdasarkan pada tabel 3, hasil analisa regresi ganda didapatkan R Square sebesar 0,109. Hal tersebut menunjukkan bahwa peran variabel prediktor yaitu contextual support and barrier sebesar 10,9\% terhadap variabel kriteria career indecision.

Tabel 4. Peranan Masing-Masing Dimensi

\begin{tabular}{ccccc}
\hline Model & & Sig & B & Beta Estimate \\
\hline 1 & (constant) & 0,000 & 34,356 & \\
& Contextual Support & 0,191 & $-0,083$ & $-0,070$ \\
& Contextual Barrier & 0,000 & 0,194 & 0,313 \\
\hline
\end{tabular}

Berdasarkan tabel 4, diketahui bahwa hanya dimensi contextual barrier yang berperan signifikan terhadap career indecision. Diperoleh persamaan regresi sebagai berikut:

$$
\mathrm{Y}=34,356+0,194 \mathrm{X}_{2}
$$

Keterangan:

$\mathrm{Y}^{\prime} \quad=$ Career indecision yang diprediksi

$\mathrm{X}_{1}=\mathrm{CB}$ (Contextual barrier)

Persamaan regresi di atas dapat dijelaskan sebagai berikut:

a. Konstanta sebesar 34,356: artinya jika contextual support $\left(\mathrm{X}_{1}\right)$ dan contextual barrier $\left(\mathrm{X}_{2}\right)$ nilainya adalah 0 , maka career indecision ( $\mathrm{Y}^{\prime}$ ) nilainya adalah 34,356.

b. Koefisien regresi variabel contextual barrier $\left(\mathrm{X}_{2}\right)$ sebesar 0,194: artinya jika variabel independen lain nilainya tetap dan contextual barrier mengalami kenaikan 1 maka career indecision (Y') akan mengalami peningkatan sebesar 34,356. Koefisien bernilai positif artinya terjadi hubungan positif antara contextual barrier dengan career indecision, semakin naik skor contextual barrier semakin naik pula skor career indecision. 
Koefisien regresi variabel contextual support ditemukan tidak berperan terhadap career indecision pada mahasiswa tingkat akhir. Oleh karena itu, penambahan skor terhadap contextual support tidak berperan signifikan terhadap penambahan skor career indecision.

Tabel 5. Uji Korelasi Dimensi Contextual Support and Barrier dan Dimensi Career Indecision

\begin{tabular}{lcccccc}
\hline \multicolumn{1}{c}{ Variabel } & $\mathbf{1}$ & $\mathbf{2}$ & $\mathbf{3}$ & $\mathbf{4}$ & $\mathbf{5}$ & $\mathbf{6}$ \\
\hline Contextual barrier (1) & & & & & & \\
Contextual support (2) & $-0,133^{*}$ & & & & \\
Lack of structure and confidence & $0,279^{* *}$ & $-0,094$ & & & \\
(3) & $0,145^{* *}$ & $-0,004$ & $0,653^{* *}$ & & & \\
Perceived external barrier (4) & $0,163^{* *}$ & 0,009 & $0,503^{* *}$ & $0,506^{* *}$ & & \\
Approach-approach conflict (5) & $0,154^{* *}$ & $-0,103$ & $0,239^{* *}$ & $0,207^{* *}$ & $0,192^{* *}$ & \\
Personal conflict $(6)$ & & & & & & \\
\hline
\end{tabular}

$* * p<0,01 ; * p<0,05$

Dalam pengujian ini, ditemukan bahwa terdapat korelasi yang signifikan antara dimensi contextual barrier dan seluruh dimensi career indecision. Namun, tidak ditemukan korelasi yang signifikan antara dimensi contextual support dan dimensi career indecision.

\section{DISKUSI}

Berdasarkan penelitian yang dilakukan, ditemukan bahwa contextual support and barrier yang dialami oleh mahasiswa berperan secara signifikan terhadap career indecision mahasiswa tingkat akhir $(\mathrm{F}=19,455 ; \mathrm{p}=0,000)$. Besarnya peranan dari contextual support and barrier terhadap career indecision mahasiswa tingkat akhir sebesar 10,9\%. Hal ini sejalan dengan penelitian Lent, Hackett dan Brown (2000), bahwa faktor penting yang secara langsung mempengaruhi individu dalam menentukan pilihan kariernya adalah faktor eksternal yang disebut oleh Lent sebagai contextual support and barrier. Selain itu, hasil penelitian ini juga sejalan dengan Kartika dan Arlinkasari (2015), yang menunjukkan bahwa individu yang mendapatkan dukungan dari lingkungan eksternal menunjukkan kemampuan dalam memilih karier yang baik, sedangkan pada individu yang mendapatkan hambatan dari lingkungan eksternal menunjukkan kemampuan dalam memilih karier yang kurang baik.

Pada penelitian ini ditemukan bahwa contextual barrier memiliki peranan signifikan terhadap career indecision mahasiswa tingkat akhir dengan nilai $(\mathrm{p}=0,000<0,05)$. Hal tersebut menunjukkan bahwa ketika mahasiswa merasakan tingkat contextual barrier yang tinggi, maka career indecision yang dirasakan akan tinggi. Hal ini dikarenakan ketika seseorang mendapatkan hambatan (barrier) yang tinggi dari lingkungan dapat mempengaruhi semua dimensi yang terdapat pada career indecision. Dapat terlihat pula berdasarkan hasil uji korelasi tambahan yang peneliti lakukan terhadap dimensi contextual barrier dan dimensi career indecision.

Berdasarkan uji korelasi tambahan yang peneliti lakukan, ditemukan bahwa terdapat korelasi positif yang signifikan antara dimensi contextual barrier dan lack of structure 
and confidence $(\mathrm{p}=0,000<0,05)$, ketika seseorang menerima hambatan (barrier) dari lingkungan yang tinggi, maka lack of structure and confidence atau kurangnya pemahaman diri dan lingkungan akan meningkat. Hal ini sejalan dengan Olivera-Celdran (2011) yang mengatakan bahwa ketika seseorang memiliki pemahaman yang kurang akan diri dan pengetahuan terkait karier, maka akan membuat individu memiliki ketidakyakinan terhadap pengambilan keputusan terkait karir yang semakin tinggi. Karena kurang percaya diri dalam membuat keputusan karier menandakan adanya kecemasan dalam membuat keputusan dan pilihan terkait karier (Callanan \& Greenhaus, 1990).

Lalu, pada penelitian ini juga menunjukkan korelasi positif yang signifikan antara dimensi contextual barrier dan perceived external barrier $(\mathrm{p}=0,009<0,05)$. Ketika seseorang menerima contextual barrier yang tinggi, maka persepsi seseorang terhadap hambatan dari faktor eksternal akan meningkat. Hal ini sejalan dengan penelitian yang dilakukan oleh Kartika dan Arlinkasari (2015) yang mengatakan bahwa ketika seseorang mendapatkan hambatan yang cukup tinggi dari lingkungan saat menentukan pilihan karir, dapat membuat seseorang semakin sulit dalam menentukan pilihan karir. Dalam proses pengambilan keputusan karier, seseorang dipengaruhi oleh pihak otoritas, seperti orangtua dan guru, sehingga ketika akan mengambil keputusan seseorang akan meminta persetujuan kepada pihak otoritas (Mau, 2000). Pengaruh-pengaruh yang diberikan oleh lingkungan yang mempengaruhi persepsi individu akan hambatan eksternal yang diterima.

Selanjutnya, terdapat korelasi yang positif antara dimensi contextual barrier dan dimensi approach-approach conflict $(\mathrm{p}=0,003<0,5)$, ketika seseorang menerima contextual barrier yang tinggi, maka approach-approach conflict yang dirasakan seseorang akan meningkat. Karena, ketika seseorang memiliki dua pilihan karier yang di inginkannya, namun lingkungan tidak menyetujui kedua pilihan tersebut dan memberikan alternatif pilihan lain selain yang diinginkan. Hal tersebut dapat membuat seseorang menjadi bingung untuk menentukan pilihan karier yang tepat (Osipow, Carney \& Barak dalam Corkin, Arbona, Coleman \& Ramirez, 2008).

Penelitian ini juga menunjukkan hasil korelasi yang positif antar contextual barrier dan Personal Conflict $(\mathrm{p}=0,006<0,05)$. Ketika seseorang menerima contextual barrier yang tinggi, maka personal conflict yang dirasakan seseorang akan meningkat. Ketika seseorang memilih karier untuk memenuhi tuntutan akan kebutuhan orang lain yang dirasa penting, namun pilihan tersebut bukan pilihan yang sesuai dengan keinginannya. Pada peristiwa tersebut, dapat menimbulkan konflik dalam diri seseorang yang membuat kecemasan dalam diri meningkat dan membuatnya menjadi takut untuk menentukan pilihan karier.

Akan tetapi, pada penelitian ini ditemukan bahwa tidak terdapat peranan yang signifikan antara dimensi contextual support dan dimensi career indecision dengan nilai $(\mathrm{p}=0,191$ $>0,05$ ). Hal tersebut menunjukkan bahwa ketika mahasiswa merasakan tingkat contextual support yang tinggi, maka tidak terdapat dampak yang signifikan terhadap career indecision yang dirasakan seseorang. Hal ini sejalan dengan hasil uji korelasi tambahan yang peneliti lakukan. Berdasarkan hasil uji korelasi tambahan yang peneliti lakukan terhadap dimensi contextual support dan dimensi career indecision, tidak 
terdapat korelasi yang signifikan antara dimensi contextual support dengan seluruh dimensi career indecision. Sejalan dengan penelitian yang dilakukan oleh Patel, Salahuddin dan O'Brien (2008) gender, dukungan keluarga, dukungan instansi dan status sosial ekonomi tidak berkontribusi terhadap pemahaman individu tentang pembuatan keputusan karier (Patel, Salahuddin dan O'Brien, 2008). Ketika lingkungan mendukung pilihan karier seseorang, bisa saja pemahaman yang dimiliki sesorang terkait tindakan yang diberikan oleh lingkungan memiliki pemahaman yang berbeda. Sehingga, dukungan yang diberikan oleh lingkungan tidak berperan terhadap career indecision yang dirasakan seseorang.

Pada penelitian ini ditemukan bahwa $89,1 \%$ variabel career indecision dipengaruhi oleh faktor lain, yang tidak menjadi bagian dari penelitian ini. Lent, Hackett dan Brown (2000), dalam teorinya mengungkapkan bahwa terdapat aspek dari dalam diri seseorang yang dapat mempengaruhi kemampuan seseorang dalam memilih karir, seperti self efficacy, outcome expectation dan goal orientation. Self efficacy merupakan refleksi keyakinan diri seseorang atas kemampuan yang dimiliki untuk melakukan suatu tindakan tertentu atau perilaku spesifik, dalam hal ini membuat suatu keputusan karir (Bandura dalam Fikry, 2015; Creed, dkk., 2006). Ditemukan bahwa self efficacy memiliki kontribusi dalam memprediksi career indecision yang dirasakan oleh seseorang (Guay, Senecal, Gauthier, \& Fernet, 2003). Outcome expectation merupakan keyakinan seseorang akan konsekuensi atau hasil dari suatu perilaku. Hal ini juga menjelaskan mengenai gambaran dari konsekuensi suatu tindakan tertentu (Lent \& Brown, 2006). Goal orientation memiliki dua tipe goal yaitu, choice content goals, merujuk pada jenis aktifitas yang dilakukan untuk mencapai suatu keinginan, dan performance goals, suatu tingkat atau kualitas dari perbuatan untuk mendapatkan suatu kekuasaan (Lent \& Brown, 2006).

Penelitian ini memiliki kelebihan dan kekurangan yang dapat dijadikan pertimbangan untuk pengembangan penelitian berikutnya. Kelebihan dari penelitian ini adalah peneliti dapat menggambarkan besaran peranan antara faktor eksternal berdasarkan contextual support and barrier terhadap career indecision yang dirasakan mahasiswa. Sehingga peneliti mengetahui, diantara dimensi contextual support and barrier, dimensi apa yang paling signifikan berperan terhadap career indecision seseorang. Selain kelebihan peneliti juga menyadari kekurangan pada penelitian ini. Pada penelitian ini, peneliti menggunakan 320 sampel dengan menggunakan teknik incidental sampling. Namun, terdapat pertanyaan data demografis yang luput ditanyakan pada subjek dalam kuesioner penelitian ini yaitu asal universitas. Hal tersebut membuat peneliti tidak mengetahui bagaimana persebaran kuesioner pada setiap wilayah yang ada di Indonesia dan hasil dari penelitian ini tidak dapat di generalisasikan terhadap populasi Indonesia. 


\section{SIMPULAN DAN IMPLIKASI}

Hasil dari penelitian ini menunjukkan bahwa contextual barrier yang dialami oleh subjek signifikan berperan terhadap career indecision mahasiswa tingkat akhir. Akan tetapi, contextual support yang dirasakan subjek tidak signifikan berperan terhadap career indecision mahasiswa tingkat akhir.

Penelitian ini memberikan implikasi praktis yang dapat bermanfaat bagi institusi pendidikan (perguruan tinggi), orang tua dan calon sarjana. Berdasarkan hasil penelitian diketahui bahwa salah satu cara yang dapat dilakukan untuk mengurangi kebimbangan karier pada mahasiswa tingkat akhir adalah dengan mengurangi berbagai masalah/ faktor yang menghambat kemampuan mahasiswa dalam menentukan pilihan kariernya. Oleh karena itu, setiap perguruan tinggi sebaiknya membuat career center agar mahasiswa dapat lebih mudah mendapatkan informasi terkait karier. Orang tua juga dapat berperan dalam membantu mahasiswa seperti dengan memberikan perhatian yang besar terhadap kemauan anak untuk memudahkan anak dalam memilih karier yang terbaik. Sementara itu, calon sarjana, sebaiknya mempersiapkan manajemen karier yang tepat dengan menetapkan tujuan, peningkatan kemampuan, dan evaluasi sistematis dan logis terhadap kemajuan karier mereka.

Implikasi teoritis dari penelitian ini terkait dengan pengembangan penelitian dengan tema pengambilan keputusan karier pada mahasiswa tingkat akhir. Penelitian selanjutnya, disarankan melakukan pengembangan penelitian dengan melihat peranan faktor lain dalam teori Social Cognitive Career Theory (SCCT) yang dapat mempengaruhi pengambilan keputusan pada mahasiswa tingkat akhir, seperti self efficacy, outcome expectation dan goal orientation secara bersamaan. Selain itu, penelitian selanjutnya disarankan untuk menggunakan teknik sampling yang berbeda, seperti cluster sampling apabila objek penelitian yang akan diteliti atau sumber data sangat luas, misal penduduk dari suatu negara, propinsi atau kabupaten.

\section{REFERENSI}

Anggraini, K.S. (2012). Gambaran Kematangan Karier Pada Mahasiswa Yang Mengikuti Unit Kegiatan Mahasiswa Di Universitas Sumatera Utara. Medan. (tidak diterbitkan)

Bandura, A. (2002). Social Cognitive Theory in Cultural Context. Applied Psychology: An International Review, 51 (2), 269-290

Berdick, A. D., Bernes, K. B., Magnusson, K. C., \& Witko, K.D. (2004). Junior High Career Planning: What Students Want. Canadian Journal Of Counseling. 38 (2).

Brown, D. (2002). Career Coice and Development. San Francisco: Jossey-Bass.

Brown, S. D., \& Lent, R. W. (2005). Career Development and Counseling. New Jersey: John Wiley \& Sons, Inc. 
Callanan, G. A., \& Greenhaus, J. H. (1990). The Career indecision of Managers and Professionals: Development of a Scale and Test of a Model. Journal Of Vocational Behavior , 79-103.

Callanan, G. A., \& Greenhaus, J. H. (2006). Encyclopedia of Career Development (Vol. 1). Thousand Oaks, CA: Sage Publications, Inc.

Celdran, G.O. (2011) . Purpose in Life and Career indecision as Predictors of Academic. A Dissertation Submitted to the Faculty of The University of North Carolina at Charlotte for the degree of Doctor of Philosophy in Counseling.

Corkin, D., Arbona, C., Coleman, N., \& Ramirez, R. (2008). Dimensions Of Career indecision Among Puerto Rican College Students. Journal Of College Student Development, 49(2), 1-15. Doi: 10.1353/Csd.2008.0015.

Creed, P., Patton, W., \& Prideaux, L.-A. (2006). Causal relationship between career indecision and career decision making self efficacy: A longitudinal cros-lagged analysis. Journal of Career Development , 33 (1), 47-65.

Daniel, W. (2013). 360.000 Sarjana di Indonesia Masih Menganggur. Di Peroleh Tanggal 5 Juni 2016, Dari http:??finance.detik.com/read/2013/05/29/161124/2259348/4/2/360000-sarjanadi-indonesia-masih-menganggur.

Fikry, Z. (2015). Hubungan Otonomi dan Efikasi Diri dalam Pengambilan Keputusan Karir Terhadap Kebimbangan Karir Mahasiswa Strata-1. Tesis, Universitas Gajah Mada.

Guay, F., Senecal, C., Gauthier, L., \& Fernet, C. (2003). Predicting Career Indecision: A Self-Determination Theory Perspective. Journal of Counseling Psychology, 50,165-177.

Guay, F., Ratelle, C. F., Senecal, C., Larose, S., \& Deschenes, A. (2006). Distinguishing developmental from chronic career indecision: self efficacy, autonomy, and social support. Journal of Career Assesment , 14 (2), 235-251.

Harahap, R. F. (2014). Duh, 87\% Mahasiswa Indonesia Salah Jurusan. Di Peroleh Tanggal 25 Mei 2016, Dari https://news.okezone.com/read/2014/02/24/373/945961/duh-87-mahasiswaindonesia-salah-jurusan

Hartung, P. J., Porfeli, E. J., \& Vondracek, F. W. (2008). Career Adaptability In Childhood. The Career Development Quarterly, 57, pp. 63-74.

Helmi, A.F. (2004). Model Mahasiswa yang Berdaya Saing. Yogyakarta: Fakultas Psikologi Universitas Gunadharma. 
Huang, J.T \& Hsieh, H.H. (2011). Linking Socioeconomic Status to Social Cognitive Career Theory Factors: A Partial Least Squares Path Modeling Analysis. Journal of Career Assessment, 19.

Kartika, L. \& Arlinkasari, F. (2015). Hubungan Antara Kematangan Karier Dengan Contextual support And Barrier Pada Mahasiswa Tingkat Akhir Di Jakarta. Jurnal Psikogenesis, 3.

Kementrian Tenaga Kerja dan Transmigrasi Republik Indonesia. (2016, Oktober 13). Diambil kembali dari www.ILO.org: http//www.org/wcmsp5/groups/public/--asia/---ro-bangkok/---

Latief. (2010). Jangan Takut Salah Pilih Jurusan.. Di Unduh Pada, Dari http://edukasi.kompas.com/read/2010/04/30/16233823/Jangan.Takut.Salah.Pilih.J urusan.

Lee, K.H. (2001). A Cross Cultural Study of Career Maturity of Korean and United States High School Student. Journal of career development, 28.

Lent, R. W., \& Brown, S. D. (2003). Relation of Contextual Supports and Barriers to Choice Behavior in Engineering Majors: Test of Alternative Social Cognitive Models. Journal of Counseling Psychology. 50 (4).

Lent, R. W., \& Brown, S. D. (2006). On Conceptualizing and Assessing Social Cognitive Constructs in Career Research: A Measurement Guide. Journal Of Career Assessment. 14 (1).

Lent, R. W., Hackett, G., \& Brown. S.D. (2000). Contextual support And Barriers to Career Choice: A Social Cognitive Analysiss. Journal of Counseling Psychology, 47.

Lent, R. W., Sheu, H. B., Gloster, C. S., \& Wilkins, G. (2010). Longitudinal Test Of The Social Cognitive Model Of Choice In Engineering Students At Historically Black Universities. Journal of Vocational Behavior, 76, 387-394.

Mau, W. C. (2000). Cultural Differences in Career Decision-Making Styles and SelfEfficacy scale. Journal of Vocational Behavior, 365-378.

Mohamad. A. (2012). Sarjana Indonesia Terbanyak Kelima di Dunia. Artikel dari Merdeka.com.http://www.merdeka.com/dunia/sarjana-indonesia-terbanyakkelima-di-dunia.html. Diakses pada 3 Juni 2017

Ngantung, D. (2013). Survei Membuktikan: 60 Persen Anak Muda Indonesia Suka Berpindah Tempat Kerja. Di Peroleh Tanggal 25 Mei 2016, Dari http://www.tribunnews.com/lifestyle/2013/09/27/survei-membuktikan-60-persenanak-muda-indonesia-suka-berpindah-tempat-kerja 
Nguyen, W. W. (2011). Career Decision Making Among Chinese- American Undergraduate Students: Cultural and Contextual Influence. Desertation.

Nile, S., \& Bowlsbey, J. (2009). Career Development Interventions in The 21st century. New Jersey: Merill.

Olivera-Celdran, G. (2011). Purpose In Life And Career indecision As Predictors Of Academic Success In College. (Disertasi), The University Of North Carolina, Carolina.

Osipow, S. H. (1999). Assessing Career indecision. Journal of vocational behavior, 55, 147-154.

Patel, S. G., Salahuddin, N, M., \& O’Brien, K. M. (2008). Career Decision-Making SelfEfficacy of Vietnamese Adolescents The Role of Acculturation, Social Support, Socioeconomic Status, and Racism. Journal of Career Development. 34 (3).

Primasuari, H. (2015). Hubungan Efikasi Diri dengan Kematangan Karier pada Mahasiswa S1 Tingkat Akhir pada Beberapa Perguruan Tinggi di Yogyakarta. Skripsi, Universitas Sanata Dharma Yogyakarta.

Rachmawati, Y.E. (2012) Hubungan Antara Self Efficacy dengan Kematangan Karier pada Mahasiswa Tingkat Awal dan Tingkat Akhir di Universitas Surabaya. Jurnal Ilmiah Mahasiswa Universitas Surabaya.

Roellyana, S \& Listiyandini, R. A (2016). Peranan Optimisme terhadap Resiliensi pada Mahasiswa Tingkat Akhir yang Mengerjakan skripsi. Prosiding Konferensi Nasional Peneliti Muda Psikologi Indonesiai. 1 (1).

Sugiyono. (2013). Statistika Untuk Penelitian . Bandung: Alfabeta.

Tien, H.-L. S. (2001). Career decision-making difficulities percieved by college students in Taiwan*. Bulletin of Educational Psychology , 33 (1), 87-98.

Ukil, I.M. (2016). Career Barriers To Career Indecision: A Final-Year BBA Students View. Journal of Management Studies. 13 (1). 